\title{
ALTERNATIVA PARA ESCULTURA DA SUPERFÍCIE OCLUSAL: MATRIZ OCLUSAL
}

Juliana Chiquito ZAMBIANCO, Gabriele Fernanda ANDRADE, Gislaine Cristine MARTINS, Osnara Maria Mongruel GOMES

A escultura em dentes posteriores requer treinamento e habilidade do operador. Visando facilitar o procedimento restaurador, propôs-se com esse relato de caso mostrar uma alternativa para a escultura da superfície oclusal em dentes posteriores. Verificou-se lesão de cárie na face oclusal do dente 36. Optou-se pela técnica da matriz oclusal e restauração direta com resina composta. Realizou-se uma profilaxia com pedra-pomes e água e, a cor selecionada para a restauração com resina composta (Ice, SDI) foi a A2. Aplicou-se uma camada de glicerina hidrossolúvel gel (KY) na superfície oclusal para isolar do material restaurador temporário translúcido, flexível e fotoativado (Bioplic, Biodinâmica) utilizado para confecção da matriz oclusal. Após a remoção do tecido cariado, procedeu-se a limpeza da cavidade com clorexidina a 2\%, o procedimento adesivo e, a restauração. Na última camada, antes da fotoativação, foi colocada a matriz oclusal e feito uma pré-fotoativação durante 5 seg, retirou-se a matriz oclusal e concluiu-se a fotoativação. $\mathrm{Na}$ seqüência fez-se o acabamento e após 48 horas o polimento final. Pode-se constatar que a técnica da utilização da matriz oclusal demonstrou ser de fácil execução; possibilidade de fidelidade no restabelecimento dos detalhes anatômicos da superfície oclusal dos dentes posteriores; e, facilidade no ajuste oclusal.

Palavras-chave: Restauração Dentária Permanente; Dentística; Resinas Compostas 